\title{
Increasing Career Satisfaction for Millennial Workers: The Mediating Role of Job Engagement
}

\author{
Nur Atika Yuniarti, Ardian Adhiatma
}

To Link this Article: http://dx.doi.org/10.6007/IJARBSS/v11-i18/11620

DOI:10.6007/IJARBSS/v11-i18/11620

Received: 06 August 2021, Revised: 29 August 2021, Accepted: 20 September 2021

Published Online: 22 October 2021

In-Text Citation: (Yuniarti \& Adhiatma, 2021)

To Cite this Article: Yuniarti, A. N., \& Adhiatma, A. (2021). Increasing Career Satisfaction for Millennial Workers: The Mediating Role of Job Engagement. International Journal of Academic Research in Business and Social Sciences, 11(18), 179-190.

\section{Copyright: (C) 2021 The Author(s)}

Published by Human Resource Management Academic Research Society (www.hrmars.com)

This article is published under the Creative Commons Attribution (CC BY 4.0) license. Anyone may reproduce, distribute, translate and create derivative works of this article (for both commercial and non-commercial purposes), subject to full attribution to the original publication and authors. The full terms of this license may be seen at: http://creativecommons.org/licences/by/4.0/legalcode

Special Issue Title: TiBECVII 2021, 2021, Pg. 179 - 190

Full Terms \& Conditions of access and use can be found at http://hrmars.com/index.php/pages/detail/publication-ethics 


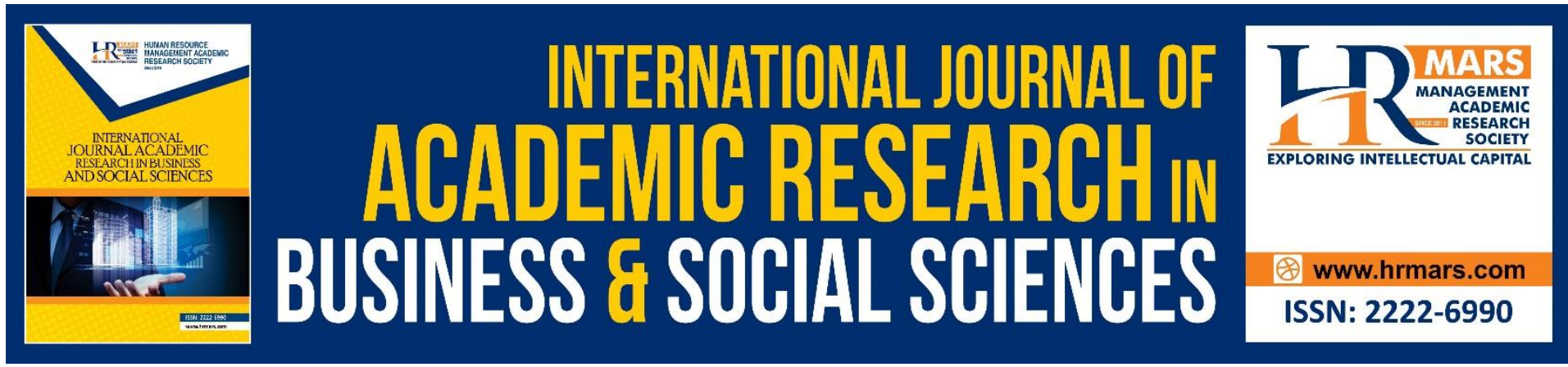

\title{
Increasing Career Satisfaction for Millennial Workers: The Mediating Role of Job Engagement
}

\author{
Nur AtikaYuniarti, Ardian Adhiatma \\ Dept. of Management, Faculty of Economics, UNISSULA, Indonesia \\ Email: nuratikayuniarti@std.unissula.ac.id, ardian@unissula.ac.id
}

\begin{abstract}
This research aims to analyze the mediating role of job engagement to increase career satisfaction for millennial workers. The ability of millennial workers to adapt a new situations is a very useful skill and must be considered by business people. This study also examined the role of digital mediated communication and spiritual work values as a determinant of job engagement. The method used was explanatory research with a quantitative approach. The respondents of this study comprised 150 lecturers aged 20 to 40 years old at Islamic Higher Education in Semarang. The respondents prioritized Islamic values with a minimum work period of 1 year. Data collection was carried out using a questionnaire via Google form. The sample used in this study were 150 lecturer respondents aged 20 until 40 years at Islamic Higher Education in Semarang who prioritized values with Islamic concepts with a minimum service period of 1 year. Data analysis used SmartPLStype 3.3. The results showed that digital mediated communication, spiritual work values, and job engagement have a positive and significant effect on career satisfaction. Meanwhile, digital mediated communication and spiritual work values have a positive significant indirect effect on career satisfaction through job engagement. It's mean, job engagement has the mediating role on career satisfaction.
\end{abstract}

Keywords: Digital Mediated Communication, Spiritual Work Values, Job Engagement, Career Satisfaction, and Millennial Workers

\section{Introduction}

Research Background

Employees in organization are a stakeholder group who very important to to develop and maintain relationships on the organization, do the best their job roles, and give an ability to shape how outsiders see of the firms. The development of digitalization has given changes all activities for global economic competition era. Therefore, many people follow the flow of technological development quickly. The technological development also change the generation, namely millennial generation (Beckner \& Beckner, 2018). They added, the millennial generation is a generation born in 1980 to 2000 who is currently $20-40$ years old. The millennial generation is famous for its generation who are proficient in using technology. This also greatly affects human resources who are required to be responsive in taking action or implementing strategies in this globalization era. The quality of human resources have an important role to determine the success of a company. It happens because human resources 
are the crucial driving factor in developing the company. The excellent human resources determine the effectiveness and efficiency of the company. (Maynard, Joseph, \& Maynard, 2006) stated that the problem on workers are the inability of workers to use their full professional potential in their job engagement. Consequently, they consider their work to be inappropriate and dissatisfied with their careers. Therefore companies must have good human resources by providing career satisfaction to millennial workers in the company (Walden \& Jung, 2017).

Career satisfaction of millennial workers is also due to the company's job engagement. Job engagement has also been considered by practitioners and researchers as important for global competitiveness (Joo \& Lee, 2017). Apart from job engagement, other support to increase career satisfaction on companies in form of digital mediated communication is needed. Millennial's ability to adapt a new technology is a beneficialskills that should benoticed carefully. Most researchers acknowledge that digital communication is the best method to accelerate the process in an organization(Bordi \& Okkonen, 2018). Job satisfaction is crucial in an organization because it can give an impact on the various progress and changes. Career satisfaction is the attitude or feelings of employees towards pleasant or unpleasant aspects of work following the assessment of each employee, (McKevitt, Carbery \& Lyons, 2017). The career satisfaction achieved by millennial workers for the company is also due to the company's job engagement. Job engagement has also been considered by practitioners and researchers as for global competitiveness (Saks, 2006).

Job engagement is an important factor that facilitates the achievement of career satisfaction in the company. The need for companies to have a positive response and meet the conditions needed by millennial workers is marked by dedication, enthusiasm, and a sense of belonging on their job (Bakker \& Schaufeli, 2008). Job engagement is a happiness felling of the workers and feels motivated by the assigned task (Schaufeli et al., 2006). Therefore, to produce and create a more effective and efficient career satisfaction for millennial workers, it is necessary to have good job engagement in companies that can be done by existing resources, because job engagement is the most important factor in companies to maintain millennial workers and career satisfaction in the company. Apart from job engagement, another support to increase career satisfaction in companies in the form of digital mediated communication is needed to increase career satisfaction in the company. For the improving job engagement is needed a determinant variabel, that are digital mediated communication and spiritual work values.

The advancement of information technology has led to a digital generation, namely those who grow and develop in a state of having easy access to digital information technology, and it has even become a routine in their daily needs. Digital mediated communication is the right effort for companies, especially in this era of globalization. Because when the companies provide employees with communication and information about their rule on their job, workers tend to work hard. tend to work hard. The increased use of digital technology can affect the development of identity and employee relationship patterns in companies as well as the competencies developed by millennial workers. The increased use of digital technology can affect the development of identity and employee relationship patterns in companies as well as the competencies developed by millennial workers. It is because basically, workers have an important role on the organization to develop and maintain positive relationships with their job in the organization. They also can shape how outsiders perceive the company(Kang \& Sung, 2017). However, this is not easy to implement because in fact, millennial employees who are satisfied with their careers are very difficult to find. Therefore, 
HR development and digital mediated communication are the right efforts for companies, especially in this era of globalization. Apart from the efforts of the company, other efforts in the form of good digital mediated communication are crucial in determining job engagement to achieve high career satisfaction. Therefore, to generate and create career satisfaction for millennial workers, it is necessary to implement digital mediated communication in companies. To improve job engagement influenced by digital mediated communication that will increase career satisfaction is not enough if it is not supported by the spiritual work values of each workers.

Millennial workers currently are profit-oriented. This will certainly affect management in making decisions in companies. Millennial workers must have spiritual values. Spiritual work values are aspects of life as an integrated system that clearly emphasizes the importance of values and practices to seek blessings and mercy. When millennial workers have work values that are oriented to aspects of spiritual values, they will be a hard workers, have a commitment, dedication, work creativity, avoidance of accumulated wealth, cooperation, and competitiveness in the workplace. Hamjah et al (2020) explained that the Prophet Muhammad (SAW) encouraged Muslims to work as much as they could. This vertical orientation can be realized in companies with the spiritual work values of millennial workers. These values will be able to convince work values, strengthen social business responsibility, and have a work orientation as a virtue in human life. By this hadith, workers will better interpret the meaning of work sincerely. With adherence to values based on the Qur'an, it will create good spiritual work values for millennial work environment, strengthen social business responsibility and have a work orientation as a virtue in human life. Based on this idea, further research is needed to implement a strategy that focuses on the millennial workers. Therefore this study examined millennial workers, namely lecturers aged 20 to 40 years old. This research will discuss the relationship between digital mediated communication, spiritual work values, job engagement on career satisfaction, which focuses on millennial workers in an organization that can later be developed and then practiced by the millennial workers.

The formulation of the problem of this research is "How to increase career satisfaction for the millennial workers based on job engagement mediating role".

\section{Literature Review}

\section{Digital Mediated Communication}

Digital mediated communication is defined as a process of delivering accurate information quickly and flexibly from one party to another using communication means (Bordi \& Okkonen, 2018). According to (Walden \& Jung, 2017) said that digital mediated communication is a process to convince with the digital communication who relations power are built and challenged in every sphere of social practice. Then the research conducted by (Kick, 2015) explained that digital communication is the great way who apply in orgainzation to increase the speed of business processes. So, it can be concluded that digital mediated communication is a communication that is carried out using a virtual system in a company to meet the demands and challenges of the digital world.

\section{Spiritual Work Values}

Spirituality work values is an innate and universal value for extraordinary meaning in one's life (Joelle \& Coelho, 2019). Research according to (Roof, 2015) showed that the work values of spirituality is one's working belief in a personal relationship with their God and always 
remember wherever which informs individual's existence and create their meaning of life. Furthermore, (Hanin Hamjah et al., 2020) defined that spiritual work values as a set of moral principles that distinguish what is right from wrong. So, it can be concluded that spiritual work values is the individual's concepts who are oriented to the pleasure of God as an organizational structure so that they have good moral and ethical principles, and can distinguish between good and true.

\section{Job Engagement}

Job engagement is a health management of work, self-improvement, leadership, and performance, and it is considered an important motivational concept(Ozyilmaz, 2020). According to(Joo \& Lee, 2017) defined that job engagement is defined as a feels working with a high dedication, as absorbing and engaging, be inspiration and energetic so that they find themselves passionately. (Raei, Goodarzi, \& Karimi, 2012) indicated that job engagement is a condition in which members of an organization identify themselves with their work. Based on the above understanding, it can be concluded that job engagement is engagement in a job to provide the best performance as a form of giving in achieving company goals.

\section{Career Satisfaction}

Career satisfaction is an individual's measurement of subjective success career, in which individual's evaluation on their professional development to personal standards and aspirations (McKevitt et al., 2017). According to (De Simone, Planta, \& Cicotto, 2018) career satisfaction is an individual's reflection, fit their values and preferences for their level career achievement. (Riaz \& Hussain Haider, 2010) added, career satisfaction is the extent to which they are currently satisfied with their income, progress, goals, acquiring new skills and progress achieved during their career span. Based on the above understanding, it can be concluded that career satisfaction is employee satisfaction with what has been done in doing work in a company.

\section{Research Method}

The samples of this study comprised lecturers aged 20 to 40 years who worked at Islamic Higher Education in Semarang, namely from Sultan Agung Islamic University (UNISSULA), Muhammadiyah University of Semarang (UNIMUS), Wahid Hasyim University (UNWAHAS), and Walisongo State Islamic University (UIN Walisongo). Totaling nearly 240 millennial lecturers from the entire study population, and the sample size was 150 individuals. This research used purposive sampling. For this purpose, sampling takes into account the characteristics of the population so that the sample becomes a representative study. By considering the sample size of the existing population, the sample size of 150 is calculated using the Slovin formula.To that end, 150 google forms were distributed to respondents and the questionnaire was finally analyzed. The data analysis used correlation test and structural equation modeling using PLS (partial least square) software to analyze the data.

\section{Variable Operational Definition (DOV)}

First, digital mediated communication is a process of delivering accurate information quickly and flexibly from one party to another by using communication tools. For instance; laptop, desktop PC, smartphone, tablet, stable internet connection (router or modem), email, social media, software for working, telephone and so forth. The indicators of digital mediated communication are ability to convey information quickly. It is also about time flexibility, 
internet usage competence, continuity of information conveyed, and online sharing information (Walden \& Jung, 2017).

Second, spiritual work value is the application divinity concept as an order in a Islamic Higher Education so that it has good moral and ethical principles and can distinguish the good and bad. The indicators of spiritual work value are meaning in life, divinity concept, trust yourself, optimism, stick to your goals, strong belief, and trust (Joelle \& Coelho, 2019).

Third, job engagement is involvement in a job to provide the best performance as a form of giving in achieving Islamic Higher Education's goals. The indicators of spiritual work values are; actively participate at work, feel that work is something interesting, seeing work as important, self-motivation to contribute and distribute, also responsible for work (Walden et al., 2017).

Fourth, career satisfaction is employee satisfaction with what has been done in doing work at the Islamic Higher Education. The indicators of career satisfaction are satisfied with their work, the achievements during work, responsibility for their work, and work with sincerity (Joo \& Lee, 2017).

\section{Results Analysis}

Tabel 1. Respondents Characteristic

\begin{tabular}{|l|c|c|}
\hline \multicolumn{1}{|c|}{ Information } & Total & Percentation \\
\hline Total Sampel & 150 & $100 \%$ \\
\hline Workplace & & \\
\hline Sultan Agung Islamic University & 49 & $32,7 \%$ \\
\hline Muhammadiyah University of Semarang & 41 & $27,3 \%$ \\
\hline Wahid Hasyim University & 30 & $20 \%$ \\
\hline Walisongo State Islamic University & 30 & $20 \%$ \\
\hline Gender & & \\
\hline Male & 67 & $44,7 \%$ \\
\hline Female & 83 & $55,7 \%$ \\
\hline Age & & \\
\hline $20-30$ years old & 38 & $74,7 \%$ \\
\hline $31-40$ years old & 112 & \\
\hline Tenure & & $100 \%$ \\
\hline$>1$ year & 150 & \\
\hline Position & & $100 \%$ \\
\hline Lecturer & 150 & \\
\hline
\end{tabular}


Tabel 2. Validity and Reliability

\begin{tabular}{|c|c|c|c|c|c|c|}
\hline \multirow{3}{*}{$\begin{array}{c}\text { Latent } \\
\text { Variables }\end{array}$} & \multirow{3}{*}{$\begin{array}{r}\text { Indicator } \\
\mathrm{s}\end{array}$} & \multicolumn{2}{|c|}{ Convergent Validity } & \multicolumn{2}{|c|}{$\begin{array}{c}\text { Internal Consistency } \\
\text { Reliability }\end{array}$} & \multirow{2}{*}{ 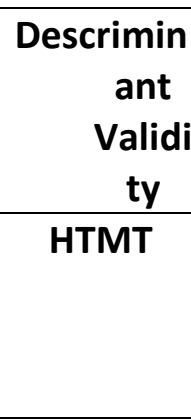 } \\
\hline & & Loadings & AVE & $\begin{array}{c}\text { Composit } \\
\text { e } \\
\text { Relia } \\
\text { bility }\end{array}$ & $\begin{array}{r}\text { Cronban } \\
\text { ch } \\
\text { Alp } \\
\text { ha }\end{array}$ & \\
\hline & & $>0.40$ & $>0.40$ & $>0.70$ & $>0.70$ & $<1$ \\
\hline \multirow{5}{*}{$\begin{array}{c}\text { Digital } \\
\text { Mediated } \\
\text { Communication }\end{array}$} & DMC.1 & 0.959 & \multirow{5}{*}{0.727} & \multirow{5}{*}{0.929} & \multirow{5}{*}{0.908} & \multirow{5}{*}{ YES } \\
\hline & DMC.2 & 0.702 & & & & \\
\hline & DMC.3 & 0.893 & & & & \\
\hline & DMC.4 & 0.959 & & & & \\
\hline & DMC.5 & 0.711 & & & & \\
\hline \multirow{7}{*}{$\begin{array}{l}\text { Spiritual Work } \\
\text { Values }\end{array}$} & SWV.1 & 0.897 & \multirow{7}{*}{0.728} & \multirow{7}{*}{0.949} & \multirow{7}{*}{0.936} & \multirow{7}{*}{ YES } \\
\hline & SWV.2 & 0.881 & & & & \\
\hline & SWV.3 & 0.951 & & & & \\
\hline & SWV.4 & 0.676 & & & & \\
\hline & SWV.5 & 0.922 & & & & \\
\hline & SWV.6 & 0.813 & & & & \\
\hline & SWV.7 & 0.801 & & & & \\
\hline \multirow{5}{*}{$\begin{array}{c}\text { Job } \\
\text { Engagement }\end{array}$} & JE.1 & 0.948 & \multirow{5}{*}{0.884} & \multirow{5}{*}{0.974} & \multirow{5}{*}{0.967} & \multirow{5}{*}{ YES } \\
\hline & JE.2 & 0.924 & & & & \\
\hline & JE.3 & 0.964 & & & & \\
\hline & JE.4 & 0.951 & & & & \\
\hline & JE.5 & 0.913 & & & & \\
\hline \multirow{4}{*}{$\begin{array}{c}\text { Career } \\
\text { Satisfaction }\end{array}$} & CS.1 & 0.918 & \multirow{4}{*}{0.776} & \multirow{4}{*}{0.933} & \multirow{4}{*}{0.903} & \multirow{4}{*}{ YES } \\
\hline & CS.2 & 0.852 & & & & \\
\hline & CS.3 & 0.888 & & & & \\
\hline & CS.4 & 0.864 & & & & \\
\hline
\end{tabular}

Based on the results of the PLS Algorithm run 1 model evaluation shows that the value of the outer loading of all variable indicators is more than 0.40.Cronbach's Alpha $>0.7$ and the value of composite reliability $>0.7$. Then based on the test results $\mathrm{R}$-square, F-square says and Q-square states that all variables have a moderate effect, except that job engagement on career satisfaction has a weak effect, namely the F-square test has a weak effect. This proves that all indicators in this research variable are valid, so there are no indicators that need to be eliminated. 
Hypothesis Test Results

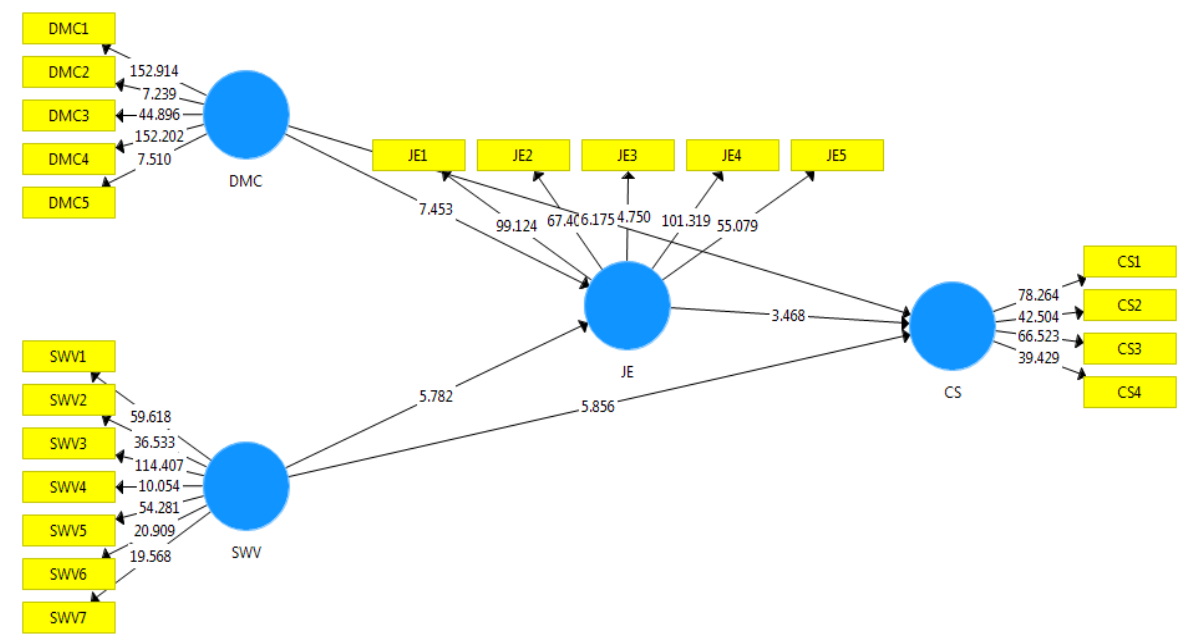

Figure 1. Struktural Model Results

Tabel 3. Path Coefficient And Hypothesis Test Results

\begin{tabular}{|l|c|c|c|c|c|c|}
\hline & $\begin{array}{c}\text { Origina } \\
\text { I } \\
\text { Sample } \\
\text { (O) }\end{array}$ & $\begin{array}{c}\text { Sampl } \\
\text { e } \\
\text { Mean } \\
\text { (M) }\end{array}$ & $\begin{array}{c}\text { Standard } \\
\text { Deviatio } \\
\text { n } \\
\text { (STDEV) }\end{array}$ & $\begin{array}{c}\text { T } \\
\text { Statistics } \\
\text { (|O/STD } \\
\text { EV|) }\end{array}$ & $\begin{array}{c}\text { P } \\
\text { Values }\end{array}$ & Result \\
\hline $\begin{array}{l}\text { Digital Mediated } \\
\text { Communication -> } \\
\text { Job Engagement }\end{array}$ & 0.416 & 0.417 & 0.056 & 7.453 & 0.000 & Accepted \\
\hline $\begin{array}{l}\text { Spiritual Work } \\
\text { Values -> } \\
\text { Job Engagement }\end{array}$ & 0.364 & 0.361 & 0.063 & 5.782 & 0.000 & Accepted \\
\hline $\begin{array}{l}\text { Job Engagement - } \\
\text { >areer } \\
\text { Satisfaction }\end{array}$ & 0.127 & 0.126 & 0.037 & 3.468 & 0.001 & Accepted \\
\hline $\begin{array}{l}\text { Digital Mediated } \\
\text { Communication -> } \\
\text { Career Satisfaction }\end{array}$ & 0.450 & 0.449 & 0.073 & 6.175 & 0.000 & Accepted \\
\hline $\begin{array}{l}\text { Spiritual Work } \\
\text { Values -> } \\
\text { Career Satisfaction }\end{array}$ & 0.433 & 0.433 & 0.074 & 5.856 & 0.000 & Accepted \\
\hline $\begin{array}{l}\text { Digital Mediated } \\
\text { Communication -> } \\
\text { Job Engagement -> } \\
\text { Career Satisfaction }\end{array}$ & 0.053 & 0.053 & 0.017 & 3.160 & 0.002 & Accepted \\
\hline $\begin{array}{l}\text { Spritual Work } \\
\text { Values -> Job } \\
\text { Engagement -> } \\
\text { Career Satisfaction }\end{array}$ & 0.046 & 0.046 & 0.016 & 2.820 & 0.005 & \\
\hline
\end{tabular}

Discussion

Digital Mediated Communication and Job Engagement 
The data results analysis by PLS type 3.3 showed that digital mediated communication has a positive and significant effect. The results of testing hypothesis 1 showed that the path coefficient $(\mathrm{O}=0.416)$ and the $t$ value of $7.453>1.96$ with a $\mathrm{p}$ value of $0.000<0.05$, then $\mathrm{HO}$ is rejected and $\mathrm{H} 1$ is accepted, so it can be concluded that digital mediated communication has a strong effect, positive and significant on job engagement. The application in the field shows that millennial lecturers who use digitally mediated communication tend to be able to interact with other lecturers or colleagues so that it is easy to convey information quickly, has time flexibility, is competent in using the internet, ensures the continuity of the information conveyed, and is able to share information online. Therefore, the first hypothesis proposed in this study, namely that digital media communication has a significant effect on work engagement, is accepted. The relationship between digital mediated communication and work engagement refers to previous research, according to (Bui, 2019) explained thatdigital mediated communication has a significant positive effect on work engagement.

Spiritual Work Values and Job Engagement

The data results analysis by PLS type 3.3 showedthat the spiritual work values has a positive and significant effect on job engagement. The results of testing hypothesis 2 showed that the path coefficient $(\mathrm{O}=0.364)$ and the $t$ value of $5.782>1.96$ with a $p$ value of $0.000<0.05$, then $\mathrm{HO}$ is rejected and $\mathrm{H} 2$ is accepted, so it can be concluded that the spiritual work value has a strong, positive and positive effect. significant to job engagement. Application in the field shows that millennial lecturers who have spiritual values tend to be more engaged in their work, this happens because when someone has high spiritual values they will know that their purpose in life in the world is to seek the pleasure of Allah alone. So that they are always responsible for what they do, including responsibility for job engagement. Therefore, the second hypothesis proposed in this study, namely the spiritual work values has a significant effect on job engagement, is accepted. The relationship between the spiritual value of work and job engagement refers to previous research, according to (Bickerton, Miner, Dowson, \& Griffin, 2014) explained that the spiritual work values has a significant positive effect on job engagement.

\section{Job Engagement and Career Satisfaction}

The data results analysis by PLS type 3.3 showed that job engagement has a positive and significant effect on career satisfaction. The results of testing hypothesis showed that job engagement has a positive and significant effect on career satisfaction with a path coefficient $(\mathrm{O}=0.127)$ and $\mathrm{t}$ values $3,468>1.96$ with $\mathrm{p}$ values showing $0.001<0.05$, then $\mathrm{H} 0$ is rejected and $\mathrm{H} 3$ is accepted, so it can be concluded that job engagement has a strong, positive and significant effect on career satisfaction. Application in the field shows shows that millennial lecturers who have work engagement tend to have a higher level of satisfaction with their work, this happens because when someone is engaged in their work they will be more satisfied with what they have done. Therefore, they always participate in work. Thus, the third hypothesis proposed in this study, namely job engagement has a significant effect on career satisfaction, is accepted. The relationship between job engagement and career satisfaction refer to previous research, according to (Joo \& Lee, 2017) explained that job engagement has a significant positive effect on career satisfaction.

Digital Mediated Communication and Career Satisfaction

The data results analysis by PLS type 3.3 showedthat digital mediated communication has a positive and significant effect on career satisfaction. The results of testing hypothesis showedthat digital mediated communication has a positive and significant effect on career 
satisfaction with a path coefficient $(O=0.450)$ and $t$ values $6,175>1.96$ with $p$ values showing $0.000<0.05$, then $\mathrm{HO}$ is rejected and $\mathrm{H} 4$ is accepted, so it can be concluded that digital mediated communication has a strong, positive and significant relationship to career satisfaction. Implementation in the field shows that lecturers who use digital mediated communication tend to be more satisfied with their careers, because they can easily convey information quickly, have time flexibility, are competent to use the internet, ensure continuity of information is conveyed, and share information online. The role of digital mediated communication at Islamic universities in Semarang will learn how to manage its business by mastering websites, using applications, skills in operating technology, and responding to any cultural changes in the work environment. Thus, the fourth hypothesis proposed in this study, namely digital mediated communication has a significant effect on career satisfaction, is accepted. The relationship between digital mediated communication and career satisfaction refer to previous research, according to(Colbert, Yee, \& George, 2016)explained that digital mediated communication has a significant positive effect on career satisfaction.

\section{Spiritual Work Values and Career Satisfaction}

The data results analysis by PLS type 3.3 showedthat spiritual work values has a positive and significant effect on career satisfaction. The results of hypothesis testing showed that spiritual work values have a positive and significant effect on career satisfaction with a path coefficient $(\mathrm{O}=0.433)$ and $\mathrm{t}$ values $5,856>1.96$ with $\mathrm{p}$ values showing $0.000<0.05$ then $\mathrm{H} 0$ is rejected and $\mathrm{H} 5$ is accepted, so it can be concluded that spiritual work values have a strong, positive and significant relationship influence on career satisfaction. Implementation in the field shows that millennial lecturers who have spiritual values tend to have a higher level of career satisfaction. With the spiritual work values they have, they will better interpret the meaning of a work that is being carried out and have a meaning in life and responsibility for the pleasure of God, they will be more sincere in what they do and more easily satisfied with their work. Thus, the fifth hypothesis proposed in this study, namely spiritual work values have a significant effect on career satisfaction, is accepted. The relationship between spiritual work values and caeer satisfaction refer to previous research, according to (Pio \& Tampi, 2018) explained that spiritual work values has a significant positive effect on career satisfaction.

\section{The Mediating Role of Job Engagement}

The data results analysis by PLS type 3.3 showedthat job engagement has a positive and significant mediating effectbeetween digital mediated communication and spiritual work values on career satisfaction. The results of hypothesis testing showed that job engagement have a positive and significant mediating effect between digital mediated communication on career satisfaction with a path coefficient $(\mathrm{O}=0.433)$ and $t$ values $3.160>1.96$ with $p$ values showing $0.002<0.05$, then job engagement also have a positif and significant mediating effect between spiritual work values on career satisfaction with a path coefficient $(\mathrm{O}=0.046)$ and $t$ values $2.820>1.96$ with $\mathrm{p}$ values showing $0.005<0.05$, then $\mathrm{H} 0$ is rejected and $\mathrm{H} 6$ is accepted, so it can be concluded that job engagement have a strong, positive and significant a mediating effect on career satisfaction. Supporting (Joo \& Lee, 2017) research, job engagement turned out to support increasing career satisfaction. Despite its apparent effect, no researchers have investigated the relationship between job engagement and career satisfaction. Job engagement has been succes mediated the relationship between digital mediated communication and spiritual work values on career satisfaction. 


\section{Conclusions and Recommendations}

\section{Conclusion}

Increase career satisfaction on millennial workers can be accured with the mediating role of job engagement. Digital mediated communication and spiritual work values are determinant for job engagement which has a very important role to increase career satisfaction. These findings also contribute to the development of theories about problems on millennial workers, when workers have high engagement in their job, will be satisfied with their career, and feel more well-being in their lives (Joo \& Lee, 2017).

\section{Managerial Implications}

Millennial lecturers consider that job engagement is considered important in increasing career satisfaction, so Islamic Higher Education in Semarang efforts must make a sustainable manner to strive job engagement by aplying digital mediated communication and spiritual work values on the workplace.

\section{Limitations and Future Research}

Limitations this research is the nature of the available evidence, most clearly in practice digital mediated communication can lead to changes cause people to changeuse of digital. As research conducted by (Bordi \& Okkonen, 2018) showed that time spent in digital mediation can reduce meaning interactions with significant others, thereforelead to a decrease in wellbeing. Evidence in this study is limited to the effects of using digital. Unbalance in the literature in terms of study design calls us for research more longitudinal studies in order to get different results. Therefore the need for research with longitudinal or experimental methods in future. Then, the questionnaire of this research was taken at the transtition between normal to pandemic, when the sample was taken during the pandemic, the research questions should also be adjusted. Because it will produce different things. Future research can develop this research model, or can re-examine it during a pandemic.

\section{References}

Bakker, A. B., \& Schaufeli, W. B. (2008). Positive organizational behavior: Engaged employees in flourishing organizations. Journal of Organizational Behavior, 29(2), 147-154. https://doi.org/10.1002/job.515

Beckner, K., \& Beckner, K. (2018). Managing Millenial Workers: A Multigenerational Approach. 1.

Bickerton, G. R., Miner, M. H., Dowson, M., \& Griffin, B. (2014). Spiritual resources and work engagement among religious workers: A three-wave longitudinal study. Journal of Occupational and Organizational Psychology, 87(2), 370-391. https://doi.org/10.1111/joop.12052

Bordi, L., \& Okkonen, J. (2018). Communication in the Digital Work Environment: Implications for Wellbeing at Work 1. 8(April).

Bui, L. (2019). Internal communication in the digital workplace: digital communication channels and employee engagement. (September).

Colbert, A., Yee, N., \& George, G. (2016). Institutional Knowledge at Singapore Management University The digital workforce and the workplace of the future. 2016, 731-739.

De Simone, S., Planta, A., \& Cicotto, G. (2018). The role of job satisfaction, work engagement, self-efficacy and agentic capacities on nurses' turnover intention and patient satisfaction. Applied Nursing Research, 39(October 2017), 130-140.

https://doi.org/10.1016/j.apnr.2017.11.004 
Joelle, M., \& Coelho, A. M. (2019). The impact of spirituality at work on workers' attitudes and individual performance. International Journal of Human Resource Management, 30(7), 1111-1135. https://doi.org/10.1080/09585192.2017.1314312

Joo, B. K., \& Lee, I. (2017). Workplace happiness: work engagement, career satisfaction, and subjective well-being. Evidence-Based HRM, 5(2), 206-221. https://doi.org/10.1108/EBHRM-04-2015-0011

Kang, M., \& Sung, M. (2017). How symmetrical employee communication leads to employee engagement and positive employee communication behaviors: The mediation of employee-organization relationships. Journal of Communication Management, 21(1), 82-102. https://doi.org/10.1108/JCOM-04-2016-0026

Kick, A. L. (2015). How Generation Z's Reliance on Digital Communication Can Affect Future Workplace Relationships. 13(2), 214-223.

Maynard, D. C., Joseph, T. A., \& Maynard, A. M. (2006). 2006-Maynard-Joseph-Maynard.pdf. Journal of Organizational Behavior, Vol. 27, pp. 509-536.

McKevitt, D., Carbery, R., \& Lyons, A. (2017). A profession but not a career? Work identity and career satisfaction in project management. International Journal of Project Management, 35(8), 1673-1682. https://doi.org/10.1016/j.ijproman.2017.07.010

Ozyilmaz, A. (2020). Hope and human capital enhance job engagement to improve workplace outcomes. Journal of Occupational and Organizational Psychology, 93(1), 187-214. https://doi.org/10.1111/joop.12289

Pio, R. J., \& Tampi, J. R. E. (2018). The influence of spiritual leadership on quality of work life, job satisfaction and organizational citizenship behavior. International Journal of Law and Management, 60(2), 757-767. https://doi.org/10.1108/IJLMA-03-2017-0028

Raei, M., Goodarzi, M., \& Karimi, Z. (2012). The effect of spiritual values on employees ' organizational commitment and its models. 62, 159-166. https://doi.org/10.1016/j.sbspro.2012.09.025

Riaz, A., \& Haider, H. M. (2010). Role of transformational and transactional leadership on job satisfaction and career satisfaction. Business and Economic Horizons, 1, 29-38. https://doi.org/10.15208/beh.2010.05

Roof, R. A. (2015). The Association of Individual Spirituality on Employee Engagement : The Spirit at Work. Journal of Business Ethics, 585-599. https://doi.org/10.1007/s10551-0142246-0

Saks, A. M. (2006). Antecedents and consequences of employee engagement. Journal of Managerial Psychology, 21(7), 600-619. https://doi.org/10.1108/02683940610690169

Schaufeli, W. B., Bakker, A. B., \& Salanova, M. (2006). The measurement of work engagement with a short questionnaire: A cross-national study. Educational and Psychological Measurement, 66(4), 701-716. https://doi.org/10.1177/0013164405282471

Walden, J., \& Jung, E. H. (2017). Employee communication, job engagement, and organizational commitment : A study of members of the Millennial Generation. 29, 7389. 